\title{
The Role Of Cooperative Education In Economic Development Of Co-operators In Calabar Metropolis
}

\author{
Cecilia A. Beshel, Ph.D \\ Department of Continuing Education and \\ Development Studies \\ University of Calabar. Calabar \\ Godwin Bullem Anthony, Ph.D \\ Department of Continuing Education and \\ Development Studies \\ University of Calabar. Calabar
}

\begin{abstract}
Cooperative is seen as the joining efforts by a group of people with liked-minds to help each other out of a helpless situation with the aim of improving their conditions of living and for socio-economic improvement. One of the principles governing the operators of cooperatives has to do with cooperative education, to help in the achievement and sustenance of such cooperatives. This study was therefore carried out to investigate the role of cooperative education in the economic development of members in Calabar Metropolis. Four null hypotheses were formulated to guide the study. Literature was reviewed based on the variables used for the study. The population of the study was 329 while a sample of 150 was drawn and used for the study. The questionnaire was the main instrument used for the study. Analysis was done using the one-way analysis of variance. The result of the analysis reveals that cooperative education influence co-operators in terms of the living standard of the cooperators, their businesses, employment opportunities and awareness on loan schemes. It was recommended that more societies should intensify their cooperative education activities.
\end{abstract}

Key words: Cooperative, Education, Economic, Development.

\section{INTRODUCTION}

Economic development is a tem synonymous with growth and progress in the living standard of the citizens of a country. It is frequently used by economist, politicians and government. It is the process by which the emerging economics becomes advance economics where countries with low standard of living gradually become the countries with high standard of living.

As stated in market businessnews.com (2019). Economic development refers to economic growth accompanied by changes in outfit distribution and economic structure. Its main concern to with quality improvements, the introduction of new goods and services, risk mitigation and the dynamics of innovation and entrepreneurship to increase skills and business acquirement.

Economic development typically involves improvement in a variety of indicators such as literacy rate, life expectancy and poverty rates. It is likely to lead families and individuals to use their heightened incomes to increase expenditures which in turns further human development. Economic development in Calabar Municipality and Calabar south is not viable. Despite the development 


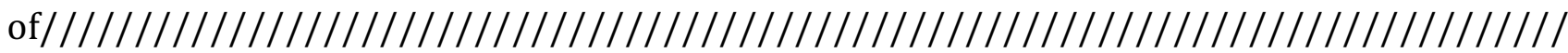
$/ / / / / / / / / / / / / / / / / / / / / / / / / / / / / / / / / / / / / / / / / / / / / / / / / / / / / / / / / / / / / / / / /$ tourism centres in the area by pass administrations and the industrialisation drive of the present government unemployment and poverty are still in the area. The two major problems this two society intending to achieve economic growth and development must tackle this two before thing of other infrastructural development. First, becoming worrisome. Each year, hundreds of youths living in the area graduate from secondary schools and some from universities, yet there is no job created for these young graduates. While some youth who graduate from secondary school advance to university educating, others may lack the means to do that immediately. Those who do not attend university education become job seekers. On the other hand, those who graduate from universities seek employment in their field of endeavours but to no avail. This situation of youth unemployment as risen to the extent that many youths have resorted to taking any kind of job just to survive. Some still engage on illegal businesses such as road blocks, illegal tax collecting, cooperate begging, stealing and looting from people's shop etc.

Poverty has continuously ravaged the lives of people in Calabar Municipality and Calabar south. Many youth live with very low income, while are solely dependent on others for survival. Others just wait for when opportunity will knock on their door for job. Some lack even the means to cater for their health needs. Some have reached the age of marriage but do not have the means to get married. To further worsen the situation, the introduction of nairabet has cost many youths their means of survival. Some youths who are not employed, believe it that the can make it with nairabet by spending the little money they have to play the game every week. Some do this for years without winning a single prediction.

However, in an area when some people feel powerless to change their lives, cooperatives represents a strong, vibrant and viable economic alternative. Cooperatives are formed to meet people's mutual needs. They are based on the powerful idea that together, a group of people can achieve goals that might not achieve at individual level.

Cooperative is seen as the joining of efforts by a group of people to help each other out of a helpless situation with the aim of improving their living conditions and for socio-economic improvement. There are certain principles governing the operations of cooperative societies the world-over of such principles has to do with "cooperative education" which necessitate the prompt information to members to understand the ideas behind formation of cooperatives, their roles, responsibilities, objectives, rights and privileges as members as well as the benefits derivable from being members of cooperative. Under this principle too, cooperatives are expected to carry out training of members and staff of the cooperative in areas like literacy, outright training in 3Rs to the stack illiterate members through evening literacy classes, vocational literacy... where members can be given training in vocational, technical, life skills and even entrepreneurial education to enable them learn a skill or two, to help them become more functional in the society by being self-employed, or be employer of labour. Scholarships to staff to undergo training in cooperative matters in institution of learning, to make them more effective and efficient in handling cooperative issues with skills and dexterity for the growth and progress of the cooperatives and by extension leading to the socio-economic development of the members as well.

Education generally is for the training of the human mind for the understanding of the world around. So cooperative education is to train the minds of the co-operators for the understanding of their peculiar problems and the enormous possibilities available around them as a group and as individuals, to solving the problems, this is to be achieved through the 
granting of information, skills, knowledge and aptitude and creating awareness on benefits, advantages, avenues and working process and practice of cooperatives to co-operators and the general public to get them better informed about cooperatives.

In the light of the above Makem, (2002) supported by Oden (2017) explained that through conferences, seminars and workshops, publication of books, journals, articles in our daily newspapers and magazines cooperative education has contributed in no small measure to creation of the awareness of cooperative education in our society. According to UNESCO, (2005) it has prepared an education and communication programme for the promotion of cooperative education in communities, where individuals have been called upon to assume a measure of responsibility hitherto assumed by government, the principles of self-help (cooperative attitude) as a dependable variable. This is so because, cooperative education is a behaviour manifestation education, since community initiative towards development is inseparable from the attitudes of the people as can be portrayed in the way they feel, think and behave. An investigation of allied factors that may help to pattern the people's behaviour towards their development has in recent times become a subject of great scholarly concern. The people in the community have found it hard to understand that they should have a real voice in determining their wellbeing and perhaps through self-help that is supported by the government. (Undie, 2005. Beshel and Itari and Ilork, 2014).

This according to Nzeneri (2002) has been due to their open exploitation and deceit by the government. Consequent upon this, is the apathy and attitude of community dwellers towards modern cooperatives with the resultant socio-economic stagnation. Therefore, it is the multiplied causes of apathy among communities toward measures that can help ameliorate their living conditions that this study is carried out to investigate the influence of cooperative education on the economic development of community dwellers in Calabar metropolis. This study is anchored on cooperative common wealth theory which emphasizes the improvement in the socio-economic wellbeing of numbers through their collective efforts.

\section{Statement of the problem}

The laudable objectives of cooperative education are to educate the masses, raise their level of income, and improve their standard of living, making them to be self-reliant and economically viable.

It is worthy of note that no economic development of the society can take place without the cooperation of people in the rural areas. Arising from this, government has realized the immense benefits of cooperative education by introducing courses in universities across the country ranging from certificates, diploma and degree awarding programmes to increase awareness on cooperative education in order to improve economic development and the standard of living of the people. University of Calabar which is situated in Calabar Metropolis offer courses in cooperative management which would have been a plus to the development of cooperatives by the youths.

This study therefore investigate how the existing cooperatives has employ cooperative education to enhance the economic development of Calabar people in Cross River State with regards to their ability to mobilize resource, to improve upon their standards of living, business enterprises, employment opportunities and awareness on loan schemes for entrepreneur and economic advancement in the area. 


\section{Statement of hypotheses}

1. There is no significant influence of cooperative education on the living standard of the Calabar people in Cross River State.

2. There is no significant influence of cooperative education on business enterprises of the Calabar people in Cross River State.

3. There is no significant influence of cooperative education on employment opportunities of cooperators in Calabar Metropolis.

4. Cooperative education does not significant influence awareness of loan schemes for entrepreneurs in amongst co-operators in Calabar Metropolis.

\section{Definition of concepts}

Cooperative: Cooperative is seen here as a form of organization wherein persons voluntarily associate together as human beings on a basis of equality for the promotion of their interests, and social economic wellbeing.

Improved living standard: This refers to the level of wealth, comfort material goods and necessities available to people in socio-economic class. These includes factors such as income, quality and availability of employment, class disparity rate quality and affordable of housing hours of work required to purchase necessities, gross domestic product inflation rate, number of vacation days per year affordable (or free) access to quality healthcare, quality and availability of education, the expectancy, incidence of disease, cost of goods and services infrastructure, national economic growth, economic and political stability, political and religious freedom, environmental quality climate an safety.

Employment opportunity: Job; a public transaction done for private profit, something performed ostensibly as a part of official duty, but really for private gain. It is also a piece of chance or occasional work, any definite work undertaken in gross for a fixed price.

Loan schemes: This simply means an arrangement in which a tender gives money or property to a borrower and the borrower agrees to return the property or repay the money, usually along with interest, at some future points in time, usually there is a presented time for repaying a loan and generally the lender bears the risk that the borrower may not repay a loan (though modern capital markets have developed many ways of managing this risks).

Cooperative education: Is a structured method of combining classroom-base education with practical wok experience. It is also a planned learning experience for which credits are earned that integrates classroom theory. It is seen as the process of educating the people on cooperative matters and creating awareness about activities and gains of cooperative society.

Entrepreneur: A person who makes money by starting or running a business, especially when this involves taking financial risks.

Community development: This refers to the sustained concerted actions of policy makers and communities that promote the standard of living and economic health of a specific area. It is also the increase in the standard of living in a nation population with sustained growth. Programmes or projects or business put in place to help the people earn a living.

Education: Education here refers to the training given to the co-operators to change their thinking and reasoning patterns in order to imbibe the culture of cooperation along with others to uplift their socio-economic status. 
Economic development: This refers to the process by which economic growth arising from changes in output distribution leads to increase in incomes of families which in turn leads to improved living standards.

\section{COOPRATIVE EDUCATION AND ECONOMIC DEVELOPMENT OF COOPERATOR'S Cooperative education and the living standard of the people}

Educationist and Economist alike have agreed that cooperative education is an investment in human capital. Education is a long term investment by which the society is to make a living in terms of improving the standard of living of the people, education in cooperative education is a component that has multiple roles to confirm the most important of which is to create well educated people who will bring their talent, skills, knowledge and competencies to bear as they function at various capacities in the society.

Ndubueze (2000), Beshel (2016) and Oden (2017), asserted that cooperative education is a programme which prepares the individual to earn a living in a competitive business world through participation in commercial activities. Similarly, Beshel (2011) in her study of the role of cooperative education to economic development found that the standard of living of members of cooperative societies is comparatively better than non-members especially those without the knowledge of cooperative education.

Commenting on the contributions of cooperative education towards the improvement of the standard of living of the people, ROW (2000) asserted that the knowledge of cooperative education enables individuals to participate successfully in business as producers of goods and services as well as managers of small medium and large scale businesses. Education is the basic skill of reading, writing and computation which is essential for individuals to function effectively in a competitive democratic society. Isa, (2002) pointed out that application of those basic skills to life situation enhances effective economic survival and quality of life. These basic academic proficiency skills are the foundation of economic, vocational and academic proficiency. Although other business disciplines share responsibilities to improve teaching of these skills, cooperative education has an obligation to support the development of the competencies involved.

Examining the relationship between cooperative education and the living standard of the people, Levitan, Garth and Marshal, (2006) noted that there is a direct positive relationship between the level of cooperative education and the standard of living of the people. These are significant testimonies of the value of cooperative education as it develop the people and increase their employment and earning capacities which in turn improves their living standards. Cooperative education has contributed in no small measure towards the improvement of the living standards of the people. Studies show that about $60 \%$ of successful businessmen who live above poverty level are people with the knowledge of cooperative education Beshel, (2012).

This is so because cooperative education assists the people who undertake it to acquire the appropriate skills, abilities and competencies both mental and physical as equipment for them to live and contribute meaningfully to the development of the society. Nowadays school leavers and those without cooperative education experience difficulty in finding jobs and as a result they live in misery, people's attitude towards cooperative education appears to be changing the aspiration of individuals for a better standard of living than ever before. People now look at cooperative education as a means via which students may rise above poverty level, live a better life through their application of the knowledge of cooperative societies. 
According to Udonno (2000) and Udo (2003) cooperative societies are known for their immense contributions to the development of the people and the society. Cooperative societies embark on activities which promote members enterprises/household, meeting wealth for members who in turn build structures like houses and expand their businesses (thus improving the social and economic status of the society. Apart from community development through members, cooperative societies are known to embark on some community development projects such as construction of roads, building of town hall and recreation centers, establishment of schools for educational development as well as establishment of large scale businesses for empowerment and economic development, of members and nonmembers.

\section{Cooperative education and enhanced business enterprises}

In fact, cooperative education has contributed tremendously towards the development of commerce in Nigeria and those of the industrial nations such as United States of America (USA) Canada Russia and Indian. Cooperative education is a discipline that produces skilled workers for specialized jobs. It provides its recipients with skills inventiveness, respect for dignity of labour and healthy attitude towards business organization. The contribution of cooperative education to national industrial development is very pervasive. Beshel (2016) reported that cooperative education in India was led to the development of many sectors of the economy of that country.

According to Nwaokolo (2001), cooperative education constitute a formidable force in equipping youths with the skills and competences necessary for the establishment of industries that will contribute a great deal to the survival of the nation. It provides the individuals with the knowledge, attitude and skills needed by all citizens in order to effectively manage their personal and cooperative business and economic affairs.

As a sub field in adult education, cooperative education provides the students with the skills, abilities, attitudes and for self and societal improvement. Cooperative education also provides capabilities of functioning competencies in the citizen as noted by Abu, (2003), and Etor (2009).

According to Ogwu (2002) cooperative education provide guidance to adult, students to increase their awareness of varied job opportunities and changing requirement for career entry and advancement. The programme provide training which changes in business and technological advancement and gives special attention to the development of human relation skills for industrial development. Osuala (2001) also posited that cooperative education prepares individuals for local business and other organization as well as for states and federal job opportunities.

Cooperative education performed the following additional functions in the industrial development of Nigeria;

- It prepares the individual for an about to be established business

- It provides a continuous programme of planned earning experiences designed to equip every individual who undertake it, and

- It enables the individuals to take judicious socio-economic decisions as citizens, to uplift their wellbeing.

In the words of Unlifun (2012) cooperative education is a necessary national investment for it is the key to the overall national economic development. It is the bed rock to economic survival of any nation. It is a door to economic programme and social services of any country. In the 
same vein, Arico (2002) stated that cooperative education has the capacity to develop programmes which correspond to current national economic issues such as education for improving basic skills for meeting the needs of the bilingual and bicultural population for eliminating occupational population, for eliminating occupational stereotyping for assisting people with special needs and for aiding the ordinary citizen to function effectively in the national industrial development. Investment in education in Nigeria has been enormous. Since independence, the federal and state governments spend huge sums of money each year on education of which cooperative education is an important sub-field. The importance of cooperative education in the industrial growth and development is well demonstrated in Nigeria through the inclusion of cooperative education to the curriculum of tertiary institutions of learning and also through industrial training of students which exposes the students of what is obtainable in the world of business.

Akom (2005) stated that business enterprises create the enabling environment for the development potential for entrepreneurs in the world. Similarly, Alade (2005) painted out that cooperative are known all over the world as instrumental weapons for fostering human and economic development which is synonymous with national development. This is more pronounced in developing nations, that is why a developing country like PLU in South America has given cooperative legislative recognizing by the cooperative Law No. 1526 signed by the president of FLU in December 1964 pp.71. The cooperative law interalia embodies a statement that cooperative should be promoted and protected from the stand point of national and public interest because it provides an effective system of fostering industrial development, strengthening democracy and establishing social justice.

Cooperative has many national functions among which the most prominent one is fostering of economic development. In developing countries with proper arrangement of the scale of preference, economic development is among the objective which carries the highest priority many prominent people are of the opinion that almost everything must be sacrificed to economic growth which is a child of economic development. In developing countries, "cooperatives" which cooperative education teaches is an instrument of economic progress Olayele, (2006).

According to Mba (2006) the variety of economic activities to which cooperative is a form of organization have been applied all over the world with a reasonable degree of success and those sectors are agriculture, minor irrigation small scale industry, processing marketing distribution, etc. It is important to point out that these are the major contribution of cooperatives of the socio-economic development of the country and that cooperative education is strategically taught to enhance the attainment of the much desired national development.

\section{Cooperative education and employment opportunities}

Employment in this context refers to a contribution of being profitably engaged in the actual performance of acquired knowledge skills or vocation either as a paid employee or a selfemployed business proprietor that cooperative education is concerned as a tool for achieving self-realization. The contributions of cooperatives in national development are underscored by the establishment of colleges of educator in almost all the states of the federation and most recent by the introduction of the programme at the university level. When Makem (2002) asserted that products of cooperative education are for business, she actually meant that product of cooperative education programme would always find jobs to do as soon as they leave school. The fact being established here is that, cooperative education promotes employment and prevent unemployment. This noble objective and potential of cooperative education cannot be changed. Oladabo (2000) stated that adult education plays crucial role in 
the promotion of employment in Nigeria economic survival through cooperative education. This assertion cannot be contested since, it has been collectively agreed that cooperative education teaches students how to make a living and be self-reliance as proved out by Beshel (2016).

Furthermore, the strong point of cooperative education is its ability to produce self-employed individuals who could by themselves become employers of labour. Although, the federal and state governments have been making attempts to solve the unemployment problems in the country, the fact is that individuals with cooperative education training have been making attempts to solve the unemployment problems in the country and other employment agencies to generate employment for them. Regarding this, the Federal Government of Nigeria (1990) declares; if there is training in entrepreneurship, the products on graduation establish small business on their own because they would have acquired enough skills in any of the major areas of education to enable them stand firm.

Cooperative education as a sub field of adult education became necessary in order to train its recipients to acquire skills, knowledge competencies and work related attitude that will enable them become self-dependent and also contribute meaningfully towards the socio-economic development of the country. There is this growing need for business knowledge, so cooperative education should be employ to satisfy this need. According to Chijoke (2002) Consumers and Nigerians alike need increased business knowledge in order that they select wisely from among vast quantities of good and services. There is also constant increase in interest, investment and in securities as a result of the indigenization decree. With the passage of indigenization decree of March 31, 1974, Nigerians are particularly active in business activities and therefore, need to acquire enough business knowledge to manage them and so the need for effective cooperative education. Nowadays people in all works of life attach much importance to cooperative education, many Nigerians have come to realize that they need training and skills that can make them employable or become self-reliance. In the words of Mbamalu (2001) "employment requirement are changing due to technological advancement. Presently, employers require business or cooperative education as a pre-requisite for entry into advancement in the world of work.

Cooperative education is therefore strategically taught to facilitate job acquisition, employment generation and national development in the current national development plan, various measures (including cooperative education) are adopted to broaden productive base of the economy as a strategy to achieving a strong and visible economy, enhance availability of improved technology and extensive services; both states and local governments are being encouraged to adopt measures for the integration of the informal sectors like cooperatives into the main stream of economic activities. This is because it is now realized that cooperatives are organs in achieving these objectives as they have branched into the establishment of small scale industries which has created a lot of employment opportunities for people especially those resident in rural areas.

\section{Cooperative education and awareness of loan schemes for entrepreneurs}

One of the major concern of cooperative education is the creation of awareness about credit facilities, where and how to obtain and most optimally utilize these loans for the establishment and sustainable management of business enterprises. The awareness is brought to the individual through formal instructions. According to Uchendu (2002) cooperative education facilitate the acquisition and utilization of loans by individuals for the purpose of starting a new business or expanding the productive capacity of an existing enterprise. He added that cooperative education does this through formal orientation of the individuals. However, these 
loan schemes ranges from short term (three-five months) to medium term (Five-six months) and long term loans (one year and above). An informal person chooses the scheme that will enable him or her to effectively and efficiently manage his or her enterprise after having ascertained the financial needs of the enterprise and after providing the collateral security prerequisite for the collection of the preference scheme.

Commenting on the choice of loan schemes, Undie (2005) asserted that an informal choice of a loan scheme is important because success in the management of any organization hinges in part on the level and quantum of funding. He further added that the ability to remain in business depends on judicious application of the obtained loans and ability to return the loans with the interest within the stipulated credit period. In her contribution, Tina (2000) posited that most successful business men are those who are informed and who have the ability to obtain and meaningfully utilize the available credit facilities in the management of their cooperatives and other businesses. It was also supported by Beshel and Andong and Asuquo (2017).

According to Ladan (2001) the positive contribution of cooperative in the acceleration of nation development in the private sector is partly responsible for introducing cooperative courses in Nigeria universities. The plan is to use education as an instrument to inform the intending members of cooperatives on how to get financial assistance from money lending institutions and other financially buoyant cooperatives which will enable them to embark on large scale businesses.

According to Ulako (2017) effective and efficient management of human and material resources is to a large extent dependent on the level of education of the entrepreneurs. Educating recast the intending and existing entrepreneurs on the acquisition of financial and materials resources is a pre-requisite to the funding and sustainable management of cooperatives and is very important since the level of success of the macro enterprises determine the extent of success of the objectives of the national development plan, and of cooperatives as well as other businesses.

\section{METHODOLOGY}

The area of the study was the Calabar Metropolis. The design adopted was the survey research design. The population of the study was 329 from where a sample size of 161 representing $10 \%$ was used for the study, after administration, a return rate was 150 giving a working sample for the study. The $10 \%$ was sampled across the cooperative societies and the members of the different cooperatives. The instrument used for the data collection was the questionnaire. The instrument was validated by two Senior Colleagues in the Faculty and the Department respectively.

\section{RESULTS AND DISCUSSION}

This study examines the role of cooperative education in the economic development of people in Calabar Metropolis of Cross River operators. The main independent variables are living standard of the people, business enterprises of the people, employment opportunity and awareness of loan schemes for entrepreneurs. While the dependent variable is cooperative education, the data were analysed based on the hypotheses.

\section{Hypothesis-by-hypothesis presentation and interpretation of results}

In this section, all the data generated for each hypothesis were presented. In presenting the results, each hypothesis was stated in the null form, the variable identified before the statistical 
analysis techniques. The interpretation of results was then followed immediately after all interpretations were done at 0.05 alpha levels with appropriate degree of freedom.

\section{Hypothesis one}

Hypothesis one states that; there is no significant influence of cooperative education on the living standard of co-operators in Calabar Metropolis. The independent variable is living standard of the people while the dependent variable is cooperative education.

To test this hypothesis, data were extracted from the data bank summarized and subjected statistical analysis of one way analysis of variance (ANOVA). The result is presented in Table 1.

TABLE 1

Descriptive statistics and One way analysis of variance (ANOVA) of the influence of cooperative education on the living standard of the people in Calabar Metropolis $(\mathrm{N}=150)$

\begin{tabular}{lccccc}
\hline Variance & $\mathrm{N}$ & $\overline{\mathrm{X}}$ & $\mathrm{SD}$ & \\
\hline Health education & 30 & & 11.38 & 2.124 & \\
Environmental education & 50 & & 15.21 & 0.751 & \\
Agricultural education & 70 & & 17.33 & 1.086 & \\
Total & 150 & & 43.92 & 3.961 & \\
\hline Source of variation & $\mathrm{SS}$ & $\mathrm{Df}$ & $\mathrm{MS}$ & $\mathrm{F}$ & Sig. \\
\hline Between groups & 800.317 & 2 & 405.399 & & \\
Within groups & 557.402 & 146 & 2.158 & $16.31^{*}$ & .000 \\
& & & & & \\
Total & & & & &
\end{tabular}

*Result significant at $\mathrm{p}<.05, \mathrm{df}=2$ and 148 , crit $-\mathrm{f}=3.00$

From Table 1, the calculated f-ratio of $16.31^{*}$ was found to be greater than the critical f-value of 3.00 needed for significance at 0.5 level with 148 degrees of freedom. The null hypothesis is rejected. This means that there is a significant influence of improvement on the standard of living on the economic development of co-operators in Calabar Metropolis.

\section{Hypothesis two}

There is no significant influence of setting up of business enterprise on the economic development of co-operators in Calabar Metropolis. To test this hypothesis, data were extracted from the data bank summarized and subjected statistical analysis of one way analysis of variance (ANOVA). The result is presented in Table 2.

TABLE 2

Descriptive statistics and One way analysis of variance (ANOVA) of the influence of cooperative education on the business enterprises of the people in Calabar Metropolis ( $N=150)$

\begin{tabular}{lccccc}
\hline Variance & $\mathrm{N}$ & & $\overline{\mathrm{X}}$ & $\mathrm{SD}$ & \\
\hline Entrepreneur education & 37 & & 9.21 & 2.128 & \\
Financial management & 55 & & 15.37 & 0.714 & \\
Agricultural education & 58 & & 18.31 & 1.083 & \\
Total & 150 & & 42.89 & 3.925 & \\
\hline Source of variation & $\mathrm{SS}$ & $\mathrm{df}$ & $\mathrm{MS}$ & $\mathrm{F}$ & Sig. \\
\hline Between groups & 741.513 & 2 & 531421 & & \\
Within groups & 337.211 & 146 & 2.171 & $15.27^{*}$ & .000 \\
& & & & & \\
Total & 1078.612 & 148 & & &
\end{tabular}

*Result significant at $\mathrm{p}<.05, \mathrm{df}=2$ and 148 , crit $-\mathrm{f}=3.00$ 
From Table 2, the calculated f-ratio of $15.27^{*}$ was found to be greater than the critical f-value of 3.00 needed for significance at 0.5 level with 148 degrees of freedom. The null hypothesis is rejected. This means that there is a significant influence of cooperative education on the business enterprise of co-operators in Calabar Metropolis.

\section{Hypothesis three}

There is no significant influence of creation of employment opportunities on the economic development of co-operators in Calabar Metropolis. The independent variable is living standard of co-operators while the dependent variable is cooperative education.

To test this hypothesis, data were extracted from the data bank summarized and subjected into statistical analysis of one way analysis of variance (ANOVA). The result is presented in Table 3.

TABLE 3

Descriptive statistics and One way analysis of variance (ANOVA) of the influence of cooperative education on the employment opportunities of the people in Calabar Metropolis $(\mathrm{N}=150)$

\begin{tabular}{|c|c|c|c|c|c|}
\hline Variance & $\mathrm{N}$ & & $\bar{X}$ & SD & \\
\hline Sole proprietorship & 32 & & 11.44 & 2.181 & \\
\hline $\begin{array}{l}\text { Employment in the private } \\
\text { sector }\end{array}$ & 55 & & 15.81 & 0.657 & \\
\hline Agricultural education & 63 & & 17.27 & 1.075 & \\
\hline Total & 150 & & 44.52 & 3.913 & \\
\hline Source of variation & SS & $\mathrm{df}$ & MS & $\mathrm{F}$ & Sig. \\
\hline Between groups & 797.551 & 2 & 401.371 & & \\
\hline Within groups & 413.271 & 146 & 2.143 & $17.23^{*}$ & .000 \\
\hline Total & 1210.668 & 148 & & & \\
\hline
\end{tabular}

$*$ Result significant at $\mathrm{p}<.05, \mathrm{df}=2$ and 148 , crit $-\mathrm{f}=3.00$

From Table 3, the calculated t-ratio of $17.23^{*}$ was found to be greater than the critical f-value of 3.00 needed for significance at 0.5 level with 148 degrees of freedom. The null hypothesis is rejected. This means that there is a significant influence of cooperative education on the employment opportunities of people by co-operators in Calabar Metropolis.

\section{Hypothesis four}

There is no significant influence of creation of loan scheme awareness on the economic development of co-operators in Calabar Metropolis. To test this hypothesis, data were extracted from the data bank summarized and subjected into statistical analysis of one way analysis of variance (ANOVA). The result is presented in Table 4. 


\section{TABLE 4}

Descriptive statistics and One way analysis of variance (ANOVA) of the influence of cooperative education on the employment opportunities of the people in Calabar Metropolis $(\mathrm{N}=150)$

\begin{tabular}{|c|c|c|c|c|c|}
\hline Variance & $\mathrm{N}$ & & $\bar{X}$ & SD & \\
\hline Demand loans & 40 & & 13.44 & 2.129 & \\
\hline Subsidized loans & 50 & & 15.54 & 0.617 & \\
\hline Unsecured loans & 60 & & 19.23 & 4.073 & \\
\hline Total & 150 & & 48.21 & 6.819 & \\
\hline Source of variation & SS & $\mathrm{df}$ & MS & $\mathrm{F}$ & Sig. \\
\hline Between groups & 813.219 & 2 & 418.519 & & \\
\hline Within groups & 617.511 & 146 & 2.141 & $18.11^{*}$ & .000 \\
\hline Total & 1430.73 & 148 & & & \\
\hline
\end{tabular}

*Result significant at $\mathrm{p}<.05, \mathrm{df}=2$ and 148 , crit $-\mathrm{f}=3.00$

From Table 4, the calculated f-ratio of $18.11^{*}$ was found to be greater than the critical f-value of 3.00 needed for significance at 0.05 level with 148 degrees of freedom. The null hypothesis is rejected. This means that there is a significant influence of cooperative education on awareness of loan schemes for entrepreneurs amongst co-operators in Calabar Metropolis.

\section{Cooperative education and the living standard of the people}

The statistical analysis of this hypothesis one revealed the fact that there exists a significant influence of cooperative education on the living standard of the Calabar Metropolis.

This revelation of supported by Row (2000) who asserted that the knowledge of cooperative enables individuals to participate successfully in business as producers of good and services as well as managers of small, medium and large businesses.

Education is the basic skills of reading, writing and computation which is essential for individuals to function effectively in a competitive democratic society. Also this finding is in consonance with Beshel (2011) who in her study contented that the role of cooperative education to economic development is great. She found that the standard of living of members of cooperative societies is comparatively better than non-members especially those without the knowledge of cooperative education.

\section{Cooperative education and enhanced business enterprises}

The statistical analysis of this hypothesis two revealed that there exists a significant influence of cooperative education on the business enterprises of co-operators in Calabar Metropolis.

The revelation is supported by Nwaokolo (2001), Beshel (2016) and Oden (2017) who contended that formidable force in equipping the youths with the skills and competitive aptitude necessary for the establishment of industries that will contribute a great deal to the survival of the nation; it attitude and skills needed by all citizens in order to efficiently manage their personal and cooperative business and economic affairs. Also, this finding is in consonance with Osuala (2001) who also posited that cooperative education prepares individuals for local business and other organizations as well as for states and federal jobs opportunities.

\section{Cooperative education and employment opportunities for adults}

The statistical analysis for this hypothesis three revealed the fact that there exists a significant influence of cooperative education on the employment opportunities of Calabar Metropolis. 
This revelation is supported by Oladabo (2000) who stated of that adult education of which cooperative education is a part played a survival role in the promotion of employment in Nigeria economic survival through cooperative education. This assertion cannot be contested since, in fact, it has been collectively agreed that cooperative education teaches students how to make a living. Also, this finding is in agreement with Maken (2002) who maintained that cooperative education promote employment and prevents unemployment. This noble objective and potential of cooperative education cannot be changed.

\section{Cooperative education and awareness of loan schemes for entrepreneurs}

The statistical analysis of this hypothesis four revealed to the fact that there exists a significant influence of cooperative education on awareness of loan schemes for entrepreneurs.

This revelation is supported by Undie (2005) who contested that cooperative education facilitates the acquisition and utilization of loans by individuals for the purpose of starting a new business of expanding the productive capacity of an existing enterprise.

Also, this finding is in line with Ulako (2016) who pointed out that cooperative education equips entrepreneurs with financial knowledge which enables them to manage their business and finance very well.

The study reveals that:

\section{SUMMARY}

1. There is a significant influence of cooperative education on the living standard of cooperators in Calabar Metropolis.

2. There is a significant influence of cooperative education on business enterprises of cooperators in Calabar Metropolis.

3. There is a significant influence of cooperative education on the employment opportunity of cooperators in Calabar Metropolis.

4. Cooperative educations significant influence awareness of loan schemes for entrepreneurs of cooperators in Calabar Metropolis.

\section{CONCLUSION}

With the results from the study, it is concluded that cooperative education is a potent tool in the economic development of not only the cooperative societies in Calabar Metropolis and Cross River State alone, but that it will help change the Economic futures of the whole country Nigeria for faster Economic Development if the Federal Government will make it a matter of policy and effective implementation of such policy for all other organizations, agencies and parasterters to key into it.

\section{RECOMMENDATION}

It is therefore recommended that, cooperative societies should intensify their cooperative education activities to mobilize more members as well as embrace innovative ideas that will improve members businesses, and better understanding of the business world. This will to a larger extent increase their business, income and lead to greater improve in their standard of living.

\section{References}

Abu, O. E. (2003: Tuesday June 13). Economic theory of cooperatives. Business times. Page 14.

Akom, I. I. (2005). Introduction to cooperative office education. Nandeikya: Onaivi Printers.

Alade, A. U. (2005). Fundamentals of organization and cooperative office education. Ilorin: Jet Publishers.

Beshel, C. A. \& Itari, P. I. (2014). Women's participation in consumer cooperative activities and rural development in Cross River State, Nigeria. The LEAJON: An Academic Journal of Interdisciplinary Studies, 6(1), 109-120. 
Beshel, C. A., \& Anthony, G. B. (2019). The Role Of Cooperative Education In Economic Development Of Co-operators In Calabar Metropolis. Advances in Social Sciences Research Journal, 6(5) 145-158.

Beshel, C. A. (2011). Unpublished lecture notes on cooperative education in Nigeria. Department of Adult and Continuing, University of Calabar, Calabar.

Beshel, C. A. (2016). Employing thrift-savings cooperative activities as alternative by traders in Northern senatorial district of Cross River State, Nigeria. International Journal of Continuing Education and Development Studies, Department of Continuing Education and Studies, University of Calabar, Calabar, 3(1), 169-174.

Beshel, C. A. Andong, H. A. \& Asuquo, G. B. (2017). Reducing poverty: The imperative of cooperative societies in education for Today: Journal of Faculty of Education, University of Calabar, Calabar, 13(1), 27-38.

Beshel, C. A. (2012). Evaluation of cooperative societies activities and rural development in terms of reduction of illiteracy. Seminar paper presented at Cross River State Apex cooperative workshop from $10^{\text {th }}-12^{\text {th }}$ May, 2012 at Bishop Monyark Avenue, State Housing.

Chijoke, C. C. (2002). Financing management. Abakaliku: Okey Printing Press.

Etor, R. I. (2009). Lecture notes on grassroot cooperatives and rural development. Department of adult and continuing education. University of Calabar, Calabar (Unpublished).

Ihidie, S. B. (2005: Sunday June 13). The contributions of cooperative education in economic development in economic development. The Guardian. Page 29.

Ilork, M. U. (2016). Cooperative in Nigeria: an introductory Text; Isit: brothers publishing company.

Ilork, U. V. (2017). Cooperative education and business development. Gboko: Zavid publishers.

Isa, A. B. (2002). Basic business skills. Onitsha: Africa FEB publishers.

Ladan, M. (2001). Cooperative societies and the Economy. Kano AUdu Press.

Levitan, I. Gerth, G. I. \& Marshall, L. (2006: Friday 16). Enhancing economic development through cooperative education. The Guardian Page 21.

Makam, F. P. (2002). Fundamentals of adult education. Boston: Brown little press.

Mbamalu, V. (2010). Fundamentals of vocational education in Nigeria. Kano: Audu Press.

Ndubueze, U. A. (2000). One man business. Ibadan: Evans Brothers.

Nzeneri, O. 0. (2002). The human side enterprise. New York: McGraw Hills.

Oden, J. I. (2017). Introduction to cooperative Obiakpo: Lolai printing press.

Oden, J. U. (2017). The role of cooperative education in the growth and progress of cooperative in Itam, Akwa Ibom State. Seminar paper presented at the 2017 cooperative week.

Ogwu, U. C. (2002). Cooperative education and industrial development. Port Harcourt: Fobu Printing Press.

Oladabo, A. L. (2000). Understanding business vandeikya: Onam Printing Press.

Olayele, Y. l. \& Adekola, G. (2006). Impact of cooperative societies on poverty alleviation. Education for Today, 6(1), 120.

Osuala, E. O. (2001). Vocational education in Nigeria. Nsukka: Falladu's publishing Coy.

Raw, W. (2000). Cooperative education in Nigeria. Port Harcourt: FEB Publishers.

Tina, K. C. (2000). Sole proprietors. Ikeja: New era printing company. March-July 2016 and 2017.

Tina, K. C. (2000). Sole proprietorship. Ikeja: New Era Printing Coy.

Uchendu, S.O 2002). Cooperative Education: a functional approach. Enugu: LAno publishers. (2019). Economic development and growth retrieval on Monday $17^{\text {th }}$ January.

Udo, A. (2003). The status of cooperative education in the area of information Communication Technology: the Guardian.

Ulako, S. I. (2017). Management of small scale business. Ibadan: Longman Publishers.

Ulako, Y. I. (2017). The way forward for cooperative in Nigeria. Seminar paper presented at Cross River State cooperative annual reports, held on $18^{\text {th }}-20^{\text {th }}$ September at No. Atu Street.

Unlifuns, F. E. (2002). Cooperative education: A utility education in developing economy. Journal of Business Education, 1(2), 97-104. 